\title{
ASPECTS OF MEDICAL CARE PROVISION BY OUT-OF-HOURS SERVICE AT PI "CENTRO POLIKLINIKA"
}

\author{
Kęstutis Štaras ${ }^{1,2,3}$, Audronė Juodaitė-Račkauskienè $\dot{1}^{1,3}$, Daiva Čepuraitė ${ }^{1,2}$ \\ ${ }^{1}$ Public Institution Vilnius Centro Outpatient Clinic, ${ }^{2}$ Mykolas Romeris University, \\ ${ }^{3}$ Vilnius University Faculty of Medicine
}

Key words: primary health care, personal health care institution, out-of-hours service, urgent care.

\begin{abstract}
Summary
The article reviews the operation of out-of-hours service at PI "Centro poliklinika" during the period of four years, a range of services, operational specifics and outcomes. Benchmarking of this field of foreign countries was also carried out. The article provides the findings of a questionnaire survey conducted from October through December of 2014, involving 173 respondents who were delivered care by out-of-hours service.
\end{abstract}

\section{Introduction}

In recent decades, health care systems in many countries worldwide are getting increasingly more patientoriented and focused on their needs as well as they are becoming a crucial part of the ongoing health system reform in Lithuania. Good health is an integral part of the quality of life. Access to appropriate health care services at outpatient personal health care institutions (hereinafter PHCI) after office hours is important to a well-functioning health care system [6].

A review of the experience gained by foreign countries showed that the meaning of the concept "comprehensive health care" varies significantly between countries. Therefore, the versatility of the system treated as a "universal" health care system in Europe, is not always rightly understood; the examination of the systems led to the awareness that each system is changing and complex, reflecting the country's needs and possibilities [10].

Scholarly sources, providing precise causes (the symptoms and diagnoses) of patient seeking for care at primary personal health care institutions (hereinafter - PPHCI) after office hours are rather limited, although the demand for health services of this category has increased within a few years worldwide [5].
Health care services provided at PPHCI after office hours is a new area in the primary health care system in Lithuania, that is why it is necessary to monitor, investigate and record the inconsistencies and the quality of the delivery of these services by assimilating the best practices of foreign countries.

It is relevant to take into account the fact that the provision of personal health care services at PPHCI after office hours demands a lot of responsibility on behalf of doctors due to the possibility of emergencies that involve a high risk of error [8].

Before launching an out-of-hours service at PI "Centro poliklinika" we largely examined the experience gained by England and Norway, which have already attained appropriate effectiveness of the operation and practice in this field.

The National Health Service (NHS) established in the United Kingdom in 1948 was targeted at facilitating the accessibility of appropriate and high quality health care services to all, regardless of the social status of an individual. Also, the NHS is responsible for health care provision in Northern Ireland, Scotland and Wales.

The NHS points out that the human should receive aid quickly, in the right place and at the lowest costs. In England there are private general practice centres. One such general practice employs 3-6 family doctors and 1-2 nurses. An individual is registered with a GP by neighbourhood or street. However, after office hours of PPHCI the patient can access a family doctor only in cases when it is not possible to provide medical assistance by phone.

The NHS organisation seeks to ensure a high-quality, patient-centered health care provision, promotes learning and innovation [2].

In accordance with of the recommendations provided by the Clinical commission established in England, since April 2014, the National Health Service issued regulations for health care provision to all GP practices, providing primary health care services after office hours of PPHCI, re- 
gulating monitoring of quality of services and regular preparation of reports on important issues or occurrence of inconsistencies. Therefore, a physician who intends to work as a general practitioner in order to be a good specialist in this field, must have acquired the necessary language skills, must be specially trained, must be equipped with clinical knowledge [9].

Slightly less than half of the population in England have not even heard of the general practice centres providing services after office hours of PPHCI, thus they normally call an ambulance. This problem exists because there is no authority responsible for the dissemination of information.

The services provided by NHS general practice centres after office hours of PPHCI are perceived as a greater risk, compared to day services provided by general practitioners, for very important reasons:

- General practices providing service after office hours of PPHCI usually have to deal with problems of unfamiliar patients and not always have access to the patient's medical history or medical records.

- Most commonly much more complex cases occur at night time rather than during the day, with a higher ratio of vulnerable patients with emergency care needs, as well as of patients receiving palliative care [1].

A special Report published in October 2014 by the Health Care Quality Commission in England highlights the importance and attention given to accessibility and quality of healthcare services provided by general practitioners working after office hours of PPHCI [3].

A patient survey conducted in England in 2014 showed that 60 per cent of general practitioners working at PPHCI after office hours have access to summaries of electronic patient records, which contain important information about the proper medication the patient shall take or any potential allergic reactions to it, but only 29 per cent of these service providers can make use of these detailed medical records on the patient [4].

Nevertheless, most of the patients in England are satisfied with the health services provided by general practitioners working after office hours of PPHCI and assess the services delivered as "Very good“" or „Fairly good".

The Norwegian health system is managed and funded at a national level and is designed so that all their citizens have equal opportunities, regardless of their social and economic situation, the country of origin and place of residence. The residents of the European Union, due to joint agreements with the European Union, may have access to health care services on equal terms with the local residents. Private health insurance figures are increasing by number, yet it covers only around 5 percent of all health care services.
429 Norwegian municipalities are provided additional support by the Norwegian Health Economics Administration and are responsible for funding and provision of primary health care services: promotion of a healthy lifestyle, preventive care, rehabilitation services, emergency and long-term nursing care.

The municipalities are in charge of the emergency service provision after office hours of PPHCI.

Contracts are concluded with general practitioners in accordance to which, after office hours of PHCIs the municipalities provide space, equipment, and allocate funding for the delivery of emergency services. In many locations, after PPHCI office hours, emergency services are patientfriendly as they familiarise the patient with the results of $\mathrm{X}$-ray and laboratory tests.

The National Health Network is a centralised institution that provides, ensures and performs direct cooperation between general practitioners, hospitals, nursing homes, pharmacists and other health care professionals and institutions. Each patient is assigned a unique personal identification code. Currently, almost all physicians use electronic patient records, most of them can send an extract from a medical history electronically from the hospital, yet the provision of these services in nursing homes is slower for more complex and integrated information systems requirements. At night, physicians often communicate electronically with laboratories outside their units and most of them can send prescriptions in electronic format to the chemist's. A large part of physicians may also order X-ray and specialised outpatient services directly via an electronic network. All hospitals use electronic personal health records. Lack of structured patient records, both of primary and secondary health care prevents automated data receipt; thus there is room for enhancement of the quality at the national level. Health care professionals who provide health care services after office hours of PPHCI often (but not always) try to post electronic records in the network so that important information about the patient in a few hours could reach primary health care providers on emergency visits.

The data obtained from a survey conducted in Norway show that the emergency services after office hours of PPHCI in Norway is very different between the municipalities. The supply and demand of health care services can vary independently of the medical needs [7].

The aim of the study was to evaluate the quality of personal health care provided by physicians and nurses working at out-of-hours service and the need for these services to patients. Seeking to attain this goal, attempts were made to assess the personal health care accessibility after office hours of other outpatient health care facilities, to 
determine the association between time consumption and the characteristics of respondents and provide prospects for possible operational and structural development of out-ofhours service at PI "Centro poliklinika".

OUT-OF-HOURS SERVICE OPERATION AT PI "CENTRO POLIKLINIKA" IN VILNIUS CITY

Out-of-Hours Service (hereinafter - OHS) at PI "Centro poliklinika" was established on 14 November 2011, in accordance with the Order No. V-130 of the Director of PI "Centro poliklinika", i.e."Regarding the Approval of the Descriptor for Minimum Health Care Services Quality Requirements" [11]. OHS provides primary health care and urgent care services after working hours of other PHCIs. The services are provided not only for patients registered with PI "Centro poliklinika" but also to patients of other PPHCI which have entered into a contract with PI "Centro poliklinika" for the provision of 24-hour services.

OHS employs 13 family doctors, 4 pediatricians and 13 general practice nurses. In 2012 there were 10 contracts concluded for the provision of 24-hour services between PI
"Centro poliklinika" and PPHCI, in 2013 - 18 (1.8 times more), in 2014 - 16 PHCIs (of which - 10 private and six public institutions), in 2015 - 18 PPHCI (of which - 11 private and 7 public institutions).

In 2013, OHS provided 11,885 services, of them $-4,822$ to patients registered with other PHCI, 166 of urgent care, 197 paid services. In 2014, OHS provided 10,176 services, of them $-3,736$ to patients registered with other PHCI, 49 of urgent care, 97 of paid services (Table 1).

Patients registered with other PHCI represent $42.6 \%$ of the total of visits (in $2012-11.8 \%$ ), children $-44.5 \%$ (in $2012-47.7 \%$ ), adults $-55.5 \%$ (in 2012-52. 3\%) (Table 1).

Paid services are provided for uninsured OHS patients or patients who are registered with PHCI, who did not conclude contracts for the provision of primary health care services after office hours and during holidays or weekends.

In 2014 paid services accounted for $0.92 \%$ of all services.

In 2014, the number of biochemical tests, including CRP, carried out at OHS working hours increased by 1.06 times, (Table 2).

Table 1. Number of medical services provided by OHS

\begin{tabular}{|l|l|c|c|c|c|c|c|}
\hline \multirow{2}{*}{$\begin{array}{l}\text { Seq. } \\
\text { No. } \\
\text { 1. }\end{array}$} & \multicolumn{1}{|c|}{ Patients } & \multicolumn{2}{|c|}{ Year 2012 } & \multicolumn{2}{c|}{ Year 2013 } & \multicolumn{2}{c|}{ Year 2014 } \\
\cline { 3 - 8 } & $\begin{array}{l}\text { Absolute } \\
\text { number }\end{array}$ & Percentage & $\begin{array}{c}\text { Absolute } \\
\text { number }\end{array}$ & Percentage & $\begin{array}{c}\text { Absolute } \\
\text { number }\end{array}$ & Percentage \\
\hline 2. & Total number of OHS patients & $\mathbf{3 . 3 5 3}$ & 100 & $\mathbf{1 1 . 8 8 5}$ & 100 & $\mathbf{1 0 . 1 7 6}$ & 100 \\
\hline 3. & $\begin{array}{l}\text { Children (registered with PI "Centro } \\
\text { poliklinika") }\end{array}$ & 1.598 & 47.7 & 5.291 & 44.5 & 3.981 & 39.1 \\
\hline 4. & $\begin{array}{l}\text { Adults (registered with PI "Centro } \\
\text { poliklinika") }\end{array}$ & 1.756 & 52.4 & 6.594 & 55.5 & 6.195 & 60.9 \\
\hline 5. & Patients registered with other PHCI & 396 & 11.8 & 4.822 & 42.6 & 3.736 & 36.7 \\
\hline
\end{tabular}

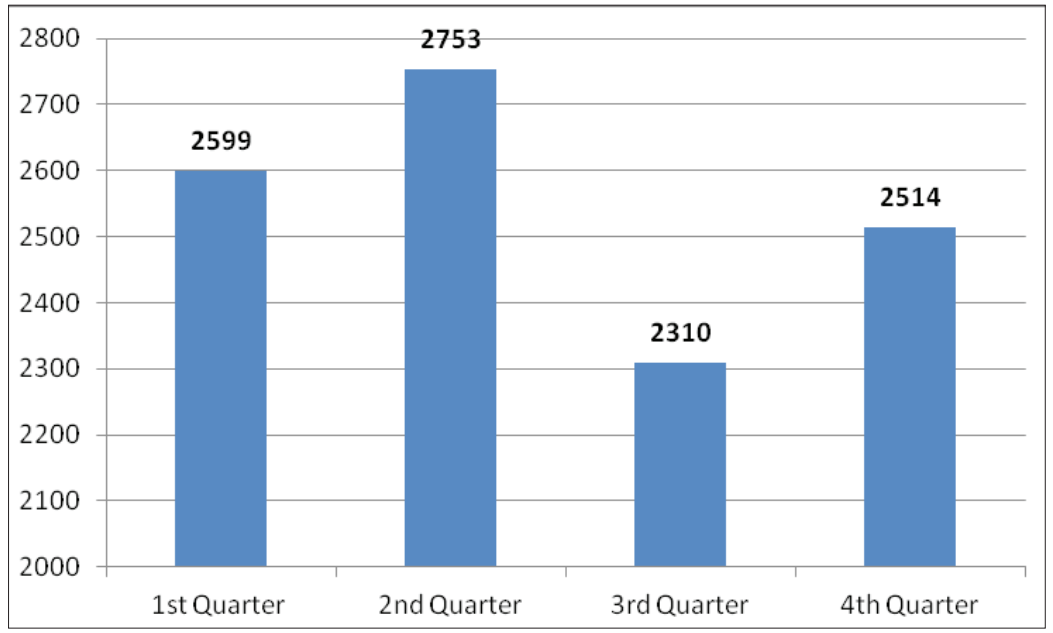

Figure 1. Quarterly distribution of patients in 2014 
Table 2. Data on laboratory tests and procedures

\begin{tabular}{|c|c|c|c|c|c|c|c|c|c|}
\hline \multirow{3}{*}{ Investigations } & \multicolumn{9}{|c|}{ Number of investigations carried out from 2012 through 2014} \\
\hline & \multicolumn{3}{|c|}{ Year 2012} & \multicolumn{3}{|c|}{ Year 2013} & \multicolumn{3}{|c|}{ Year 2014} \\
\hline & Adults & Children & $\begin{array}{c}\text { In } \\
\text { total }\end{array}$ & Adults & Children & $\begin{array}{c}\text { In } \\
\text { total }\end{array}$ & Adults & Children & $\begin{array}{c}\text { In } \\
\text { total }\end{array}$ \\
\hline $\begin{array}{l}\text { Investigations in } \\
\text { total }\end{array}$ & 172 & 447 & 619 & 582 & 972 & 1.554 & 560 & 843 & 1.403 \\
\hline Haematological tests & 71 & 228 & 299 & 155 & 159 & 314 & 118 & 92 & 210 \\
\hline \multirow{3}{*}{$\begin{array}{l}\text { Biochemical tests } \\
\text { Including: blood } \\
\text { glucose, } \\
\text { CRP }\end{array}$} & 45 & 126 & 171 & 342 & 741 & 1.083 & 361 & 691 & 1.052 \\
\hline & 8 & 0 & 8 & 2 & 2 & 4 & 3 & 1 & 4 \\
\hline & 37 & 126 & 163 & 340 & 739 & 1.079 & 358 & 690 & 1.048 \\
\hline General clinical tests & 56 & 93 & 149 & 85 & 72 & 157 & 81 & 60 & 141 \\
\hline
\end{tabular}

Table 3. Data on services provided in a GP's procedure room

\begin{tabular}{|l|c|c|c|}
\hline \multirow{2}{*}{ Procedures } & \multicolumn{2}{|c|}{ Number of procedures performed from 2012 through 2014 } \\
\cline { 2 - 4 } & $\mathbf{2 0 1 2}$ & $\mathbf{2 0 1 3}$ & $\mathbf{2 0 1 4}$ \\
\hline Total number of procedures & $\mathbf{6 1 9}$ & $\mathbf{1 0 8 0}$ & $\mathbf{2 0 3 9}$ \\
\hline INJECTIONS: & 404 & 541 & 865 \\
\hline$-\quad$ intramuscular & 297 & 384 & 209 \\
\hline$-\quad$ intravenous & 103 & 154 & 12 \\
\hline$-\quad$ infusion & 4 & 3 & 602 \\
\hline Dressing & 26 & 177 & 351 \\
\hline ECG & 189 & 362 & \\
\hline
\end{tabular}

In 2014 , the increase of $88.8 \%$ in the amount of procedures performed at OHS is observed, compared to 2013. Also, the number of dressings provided in 2014 rose by 3.4 times (Table 3).

In 2014, an overall number of 431 patients were referred for hospitalisation (i.e., $4.24 \%$ of all the patients seeking for primary health care, compared to $4.5 \%$ in $2013,7.8 \%$ in 2012). The prevailing complaints were related to the diseases of the respiratory, digestive, circulatory system as well as certain infectious and parasitic diseases. There were 3.3 times more patients hospitalised for injuries, poisoning and other consequences of external causes while a significant decline was observed in the number of admissions for the ear and mastoid diseases and health ailments of pregnancy, childbirth and the postnatal period.

In 2014, compared with 2013, a decrease was recorded in mental and behavioral disorders ( 2 cases), diseases of the respiratory system (117 cases) (Table 4) [12].

\section{Material and methods of the study}

An anonymous questionnaire survey was used for the study. The questionnaire consisted of 21 questions. See- king to identify the characteristics of services provided by OHS, emphasis was laid on the criteria of the study, which are directly reflected in the questionnaire. The respondents were surveyed from October through December of 2014 at PI "Centro poliklinika". A total of 230 questionnaires were distributed and 173 respondents of PI "Centro poliklinika"(reversibility rate of 75.22 per cent) filled out the questionnaires. The respondents involved in the study were patients who were provided with health care services at out-of-hours service.

The patients were asked to evaluate the availability and quality of services provided by out-of-hours service. The questions involved information on the respondent's gender, age, education, which PHCI a respondent has been registered with, the reason for attendance at OHS appointments, the waiting time to see a doctor, as well as the quality of the provision of medical service.

The data collected during the survey were classified, processed and compared. The statistical data processing was performed using SPSS Version 19 software. Coding and entry errors and were determined and response frequency was calculated by means of the Frequency procedure. 
The averages were used to calculate medium-time costs. The statistical significance of the difference of response frequency distribution between discrete (nominal and ordinal) features was assessed by a nonparametric criterion Pearson Chi-square $\left(\chi^{2}\right)$ with 95 percent probability, i.e., the difference is considered to be statistically significant at $p<0.05$. The statistical - correlation (for variables without normal distribution assumption) and the direction were determined by a nonparametric Spearman correlation coefficient (rho), $\mathrm{p}<0.05$.

\section{Findings of the study}

2.1. Distribution of the respondents by socio-demographic data

Overall, 173 respondents of OHS were interviewed. Of them - 60.7 per cent $(\mathrm{N}=105)$ of women and 39.3 per cent $(\mathrm{N}=68)$ of men (Modus $=1$, female). The respondents were divided by age into three groups: group 1 consisted of the respondents aged from 18 to 49 (72.3 per cent, $\mathrm{N}=125)$, group 2 consisted of the respondents aged from 50 to 64
(16.2 per cent, $\mathrm{N}=28$ ), group 3 comprised the respondents aged 65 and over $(11.6$ per cent, $\mathrm{N}=20)($ Modus $=1$, Median $=1$, age range from 18 to 49 ).

Of all the surveyed respondents, 41 (23.7 per cent) attained secondary education, 31 (17.9 per cent) - vocational education, 28 (16.2 per cent) attained higher non-university and 73 (42.2 per cent) were university degree holders (Modus $=4$, higher education/ university degree).

2.2. Dissemination of information on out-of-hours service at PI "Centro Poliklinika"

Of the 172 respondents, 122 ( 70.9 per cent) of the respondents stated that they were registered with PI "Centro poliklinika", while 50 (29.1 per cent) - with other PHCIs.

The evaluation of the responses provided by the surveyed 135 respondents showed that even 42.2 per cent $(\mathrm{N}=$ 57 ) of respondents were impacted by the availability of outof-hours service at this institution and registered with PI "Centro poliklinika". Overall, 31.8 per cent $(\mathrm{N}=55)$ of respondents pointed out learning about this service from their

Table 4. Data on referrals for hospitalisation

\begin{tabular}{|c|c|c|c|c|}
\hline \multirow{2}{*}{$\begin{array}{l}\text { Seq. } \\
\text { No. }\end{array}$} & \multirow{2}{*}{ Diseases and ailments } & \multicolumn{3}{|c|}{$\begin{array}{l}\text { Number of patients referred for } \\
\text { hospitalisation }\end{array}$} \\
\hline & & 2012 & 2013 & 2014 \\
\hline 1. & Certain infectious and parasitic diseases & 32 & 49 & 46 \\
\hline 2. & Tumours & 0 & 1 & 0 \\
\hline 3. & $\begin{array}{l}\text { Diseases of blood and blood-forming organs and certain } \\
\text { disorders related to the immune mechanisms }\end{array}$ & 2 & 1 & 0 \\
\hline 4. & Endocrine, nutritional and metabolic diseases & 2 & 12 & 7 \\
\hline 5. & Mental and behavioral disorders & 0 & 5 & 2 \\
\hline 6. & Diseases of the nervous system & 2 & 5 & 5 \\
\hline 7. & Diseases of the eye and the ocular adnexa & 6 & 1 & 2 \\
\hline 8. & Ear and mastoid diseases & 16 & 10 & 7 \\
\hline 9. & Diseases of the circulatory system & 24 & 39 & 27 \\
\hline 10. & Diseases of the respiratory system & 74 & 140 & 117 \\
\hline 11. & Diseases of the digestive system & 48 & 102 & 76 \\
\hline 12. & Diseases of the skin and the subcutaneous tissue & 5 & 15 & 8 \\
\hline 13. & $\begin{array}{l}\text { Diseases of the connective tissue and skeletal - } \\
\text { muscular system }\end{array}$ & 1 & 2 & 4 \\
\hline 14. & Diseases of the genito-urinary system & 17 & 29 & 33 \\
\hline 15. & $\begin{array}{l}\text { Pregnancy, childbirth and the postpartum period } \\
\text { diseases }\end{array}$ & 6 & 4 & 1 \\
\hline 16. & Certain diseases of the perinatal period & 0 & 0 & 1 \\
\hline 17. & $\begin{array}{l}\text { Congenital malformations, deformations and } \\
\text { chromosomal abnormalities }\end{array}$ & 0 & 1 & 0 \\
\hline 18. & $\begin{array}{l}\text { Symptoms, signs and abnormal clinical and laboratory } \\
\text { findings, not classified elsewhere }\end{array}$ & 23 & 107 & 82 \\
\hline 19. & $\begin{array}{l}\text { Traumas, poisoning and other consequences of external } \\
\text { causes }\end{array}$ & 3 & 10 & 13 \\
\hline & In total & 261 & 533 & 431 \\
\hline
\end{tabular}




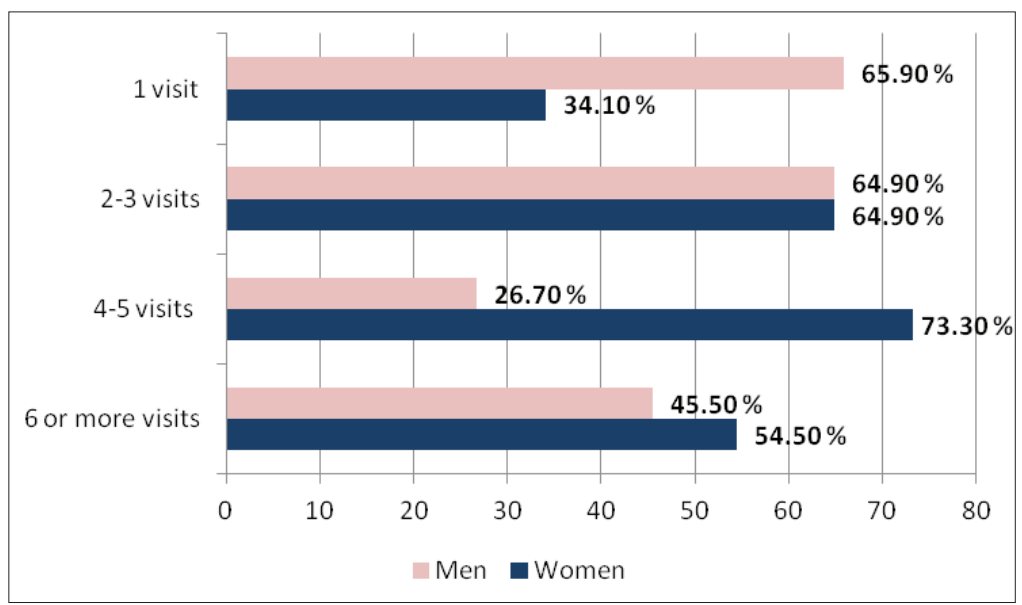

Figure 2. Distribution of the rate of respondents' visits to out-of-hours service by gender (rate of respondents by per cent) $\left(\chi^{2}=9.789, d f=3, p=0.020\right)$.

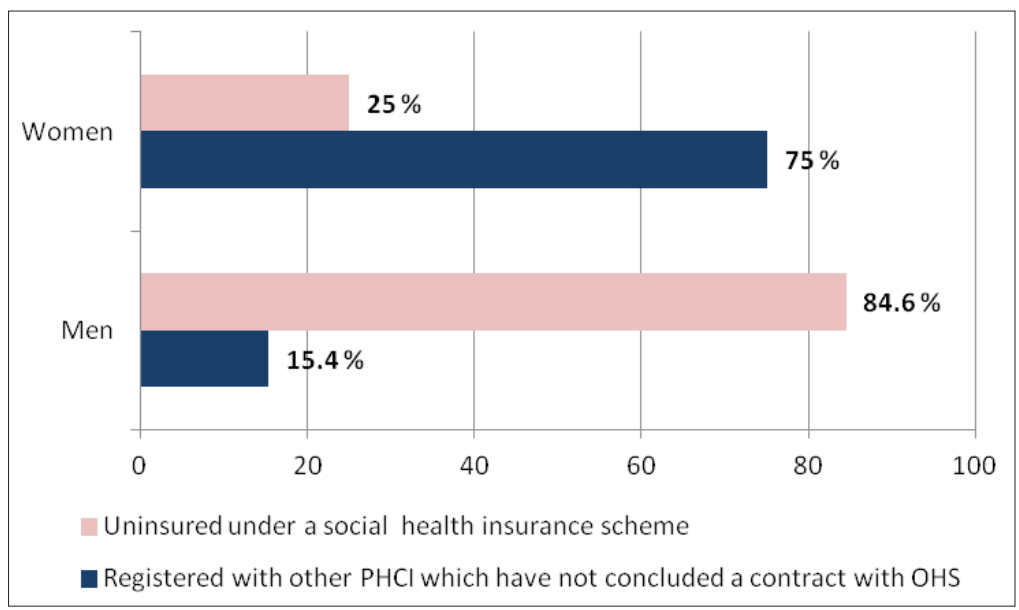

Figure 3. Distribution of respondents' paid consulting services provision by gender (rate of respondents by per cent) $\left(\chi^{2}=7.463, d f=1, p=0.06\right) .\left(X^{2}=7.463, d f=1, p=0.06\right)$

doctor, 14.5 per cent $(\mathrm{N}=25)$ - at the reception, 35.3 per cent $(\mathrm{N}=61)$ - on the Internet, 13.3 per cent $(\mathrm{N}=23)$ - from friends, relatives, 5.2 per cent $(\mathrm{N}=9)$ - from other sources.

Of 169 respondents, 84.6 per cent $(\mathrm{N}=143)$ emphasised that the provision of GP's medical care at out-of-hours service is sufficient without involvement of specialists, 15.4 per cent $(\mathrm{N}=26)$ assessed care provision without involvement of professional physicians is not sufficient. Even 99.4 per cent $(\mathrm{N}=172)$ of all respondents trusted medical health care service provided by the family doctor at out-of-hours service.

2.3. Out-of-hours service availability and performance analysis by gender of the respondents

The evaluation of the opinion of the surveyed respon- dents on how many times they have attended out-of-hours service revealed a statistically significant difference between the respondents' gender and the number of visits $\left(\chi^{2}=9.789\right.$, df $=3, p=0.020)$. The data show that the number of visits to OHS depended on sex and that women were more likely to seek for personal health care services provided by out-of-hours service rather than men. Most commonly the out-of-hours service was visited by women ( 4 - 5 times - by 73.30 per cent, 6 times and more - by 54.50 per cent) (Figure 2).

The analysis of the patients' waiting time to see a doctor did not reveal any statistically significant difference $\left(\chi^{2}=3.432, \mathrm{df}=4, \mathrm{p}=\right.$ 0.488 ), therefore, we can say that the waiting time to see a doctor did not depend on the gender. A similar time period spent on waiting for medical service was observed in both, women and men (Table 5).

A review of the responses obtained from the surveyed patients on why they were delivered paid medical service at out-of-hours service revealed a statistically significant difference between the respondents' gender and the reason for paid medical services $\left(\chi^{2}\right.$ $=7.463, \mathrm{df}=1, \mathrm{p}=0.06)$. The most common paid service was provided for women who attended out-of-hours service at PI "Centro poliklinika" but are on a contract concluded with other PHCI rather than PI "Centro poliklinika" (84.60 per cent), while men who were provided this service were most commonly not insured with social insurance ( 75 per cent). After reviewing the opinion of respondents, it was obvious that women from other PHCIs who have not concluded the contract with PI "Centro poliklinika" were in need for care provision by out-of-hours service at PI "Centro poliklinika" (Figure 3).

In assessing whether the doctor allocated enough attention during the visit, 98.9 per cent of men and 100 per cent of women pointed out that the physician paid sufficient attention during their visit. A statistically significant difference was not found $\left(\chi^{2}=1.563\right.$, df $\left.=1, \mathrm{p}=0.211\right)$, therefore, it can be stated that the doctor's focus on patients did not depend on their gender.

In assessing whether the nurse provided sufficient attention during their visit, 98.9 per cent of men and 100 per cent of women noted that the nurse allocated sufficient amount of attention during their visit. A statistically signi- 
ficant difference was not found $\left(\chi^{2}=1.555, \mathrm{df}=1, \mathrm{p}=0.212\right)$, therefore, we can state that the nurse gave the same amount of attention to both, men and women at the time of their visit.

In assessing whether the physician provided sufficient information on the patient's health status and further treatment, 98.6 per cent of women and 97.7 per cent of men noted that the information provided during their visit was sufficient. There was no statistically significant difference found $\left(\chi^{2}\right.$ $=0.208, \mathrm{df}=1, \mathrm{p}=0.645)$. In accordance with the data, we can conclude that the respondent's gender did not impact the volume of the information provided by the doctor.

The analysis of the respondents' assessment of the qualification of physicians working at out-of-hours service did not reveal any statistically significant difference $\left(\chi^{2}=1.794, \mathrm{df}\right.$ $=3, p=0.616$ ), therefore, we can state that both, men and women provided similar assessment in terms of the physicians' qualification (Table 6).

The analysis of the patients' opinion on the changes observed in organising out-ofhours service provision and the quality of services provided over the past two years revealed no statistically significant difference $\left(\chi^{2}=2.109, \mathrm{df}=2\right.$, $\mathrm{p}=0.348$ ), therefore, it can be stated that the evaluation of the organisation of work and the quality of services provided was independent of gender (Table 7).

2.4. The analysis of the availability and performance of out-of-hours services by respondent age groups

The majority of the respondents ( 40 per cent) stated that they had found out about out-of-hours service on the Internet (Table 8).

Having examined the patients' responses to the ques$\left(\chi^{2}=3.432, d f=4, p=0.488\right)$ $\left(\chi^{2}=1.794, d f=3, p=0.616\right)$

$\left(\chi^{2}=2.109, d f=2, p=0.348\right)$
Table 5. Distribution of the respondents' waiting time to see a doctor by gender (per cent)

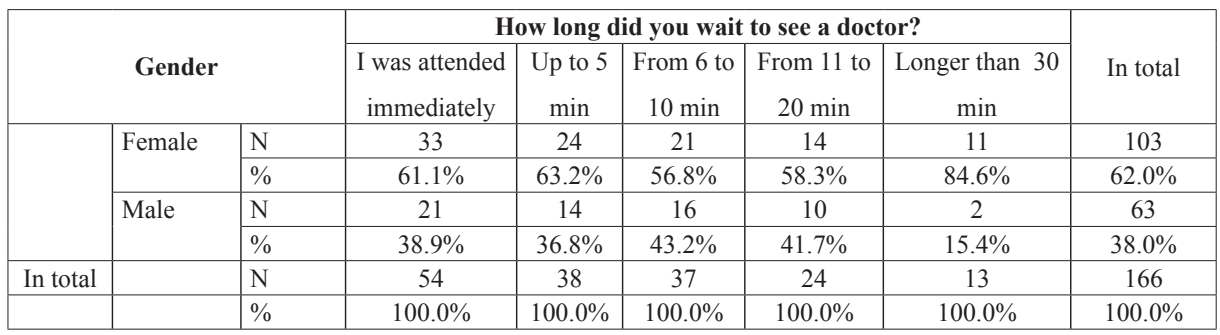

Table 6. Distribution of doctors' qualification assessment by respondents' gender (per cent)

\begin{tabular}{|c|c|c|c|c|c|c|c|}
\hline \multicolumn{3}{|c|}{ Gender } & \multicolumn{4}{|c|}{$\begin{array}{l}\text { How do you assess the qualification of physicians working } \\
\text { at out-of-hours service? }\end{array}$} & \multirow[t]{2}{*}{ In total } \\
\hline & & & Excellent & Good & Satisfactory & Poor & \\
\hline & \multirow[t]{2}{*}{ Female } & $\mathrm{N}$ & 73 & 28 & 1 & 0 & 102 \\
\hline & & $\%$ & $61.3 \%$ & $63.6 \%$ & $50.0 \%$ & $.0 \%$ & $61.4 \%$ \\
\hline & \multirow[t]{2}{*}{ Male } & $\mathrm{N}$ & 46 & 16 & 1 & 1 & 64 \\
\hline & & $\%$ & $38.7 \%$ & $36.4 \%$ & $50.0 \%$ & $100.0 \%$ & $38.6 \%$ \\
\hline \multirow[t]{2}{*}{ In total } & & $\mathrm{N}$ & 119 & 44 & 2 & 1 & 166 \\
\hline & & $\%$ & $100.0 \%$ & $100.0 \%$ & $100.0 \%$ & $100.0 \%$ & $100.0 \%$ \\
\hline
\end{tabular}

Table 7. Distribution of the evaluation of organisation of work and the quality of service provided by out-of-hours service, by respondents' gender (per cent)

\begin{tabular}{|c|c|c|c|c|c|c|}
\hline \multirow{2}{*}{\multicolumn{3}{|c|}{ Gender }} & \multicolumn{3}{|c|}{$\begin{array}{l}\text { In your opinion, has the organisation of work } \\
\text { and the quality of services provided by out-of- } \\
\text { hours service }\end{array}$} & \multirow{3}{*}{$\begin{array}{c}\text { In total } \\
80 \\
\end{array}$} \\
\hline & & & \multirow{2}{*}{$\begin{array}{c}\text { improved? } \\
50\end{array}$} & \multirow{2}{*}{\begin{tabular}{|c|} 
remained unchanged? \\
30
\end{tabular}} & \multirow{2}{*}{$\begin{array}{c}\text { worsened? } \\
0\end{array}$} & \\
\hline & Female & $\mathrm{N}$ & & & & \\
\hline & & $\%$ & $62.5 \%$ & $55.6 \%$ & $.0 \%$ & $59.3 \%$ \\
\hline & Male & $\mathrm{N}$ & 30 & 24 & 1 & 55 \\
\hline & & $\%$ & $37.5 \%$ & $44.4 \%$ & $100.0 \%$ & $40.7 \%$ \\
\hline \multirow[t]{2}{*}{ In total } & & $\mathrm{N}$ & 80 & 54 & 1 & 135 \\
\hline & & $\%$ & $100.0 \%$ & $100.0 \%$ & $100.0 \%$ & $100.0 \%$ \\
\hline
\end{tabular}

tion on how they had found out about out-of-hours service, a statistically significant difference was revealed between the patients' age group and the source of information $\left(\chi^{2}=17.148, \mathrm{df}=8, \mathrm{p}=0.029\right)$. The data show that the majority of the youngest respondents ( 40 per cent) found information on out-of-hours service on the Internet, compared with older respondents (aged 65 and over) (Table 8).

A review of the opinion of the respondents revealed that fever was the most common cause of out-of-hours service 
attendance by even 42.7 per cent $(\mathrm{N}=53)$ of the respondents of the age group from 18 to 49 , whereas the cause of the least visits, i.e. 23.4 per cent $(\mathrm{N}=29)$ was poisoning. The evaluation of the data and findings obtained from all the three age groups of respondents (aged 18 to 49, 50-64, 65 and over) showed no statistically significant difference $\left(\chi^{2}=17.886, \mathrm{df}=12, \mathrm{p}=0.119\right)$, therefore, it can be argued that the patients of all the three age groups attended out-ofhours service for similar reasons.

The evaluation of the surveyed opinions on whether out-of-hours service provides sufficient care or involvement of specialists is necessary at out-of-hours service, revealed a statistically significant difference between the respondents' age group and the statement $\left(\chi^{2}=7.395, \mathrm{df}=2\right.$, $\mathrm{p}=0.025)$. This distribution of opinions suggests that the patients aged 65 and over (26.9 per cent) prioritised health care service provision by specialists. Thus, the assessment of respondents' opinion shows that they seek for health care exceeding the scope of GP's care provided at out-of-hours service. These findings may be associated with aggravating conditions of chronic diseases suffered by older patients (Figure 4).

While assessing the patients' trust in health care services provided by a family doctor at out-of-hours services, no statistically significant difference $\left(\chi^{2}=0.386, \mathrm{df}=2, \mathrm{p}\right.$ $=0.824$ ) was observed, therefore, we can argue that the age of patients did not influence their trust in the family doctor and health care service provided by him.

The analysis of the surveyed patients waiting time to see a doctor by age group showed a statistically significant difference between the respondents' age group and the waiting time $\left(\chi^{2}=18.592, \mathrm{df}=8, \mathrm{p}=0.017\right)$. Most of the

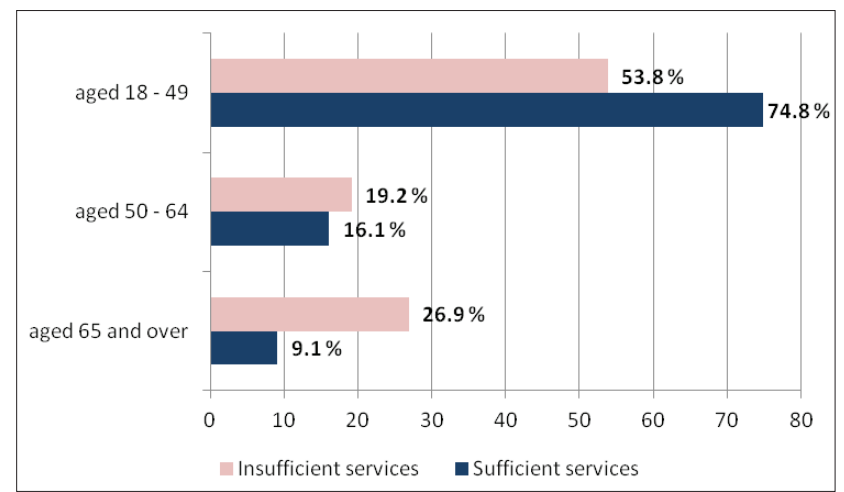

Figure 4. Distribution of responses on whether medical care provided by out-of-hours service is sufficient without involvement of specialists, by age groups (the number of respondents by per cent) $\left(X^{2}=7.395, d f=2, p=0.025\right)$.

Table 8. Distribution of sources of information on out-of-hours service by age groups (per cent) $\left(\chi^{2}=17.148, d f=8, p=0.029\right)$

\begin{tabular}{|c|c|c|c|c|c|c|c|c|}
\hline \multirow{2}{*}{\multicolumn{3}{|c|}{ Age group }} & \multicolumn{5}{|c|}{$\begin{array}{l}\text { How did you find out about out-of-hours service at PI } \\
\text { "Centro poliklinika"? }\end{array}$} & \multirow{3}{*}{$\begin{array}{c}\text { In total } \\
\\
125\end{array}$} \\
\hline & & & \multirow[t]{2}{*}{$\begin{array}{c}\text { The } \\
\text { attending } \\
\text { doctor } \\
\text { informed me } \\
35\end{array}$} & \multirow[t]{2}{*}{$\begin{array}{c}\text { At the } \\
\text { Reception } \\
17\end{array}$} & \multirow[t]{2}{*}{$\begin{array}{l}\text { On the } \\
\text { Internet } \\
50\end{array}$} & \multirow[t]{2}{*}{$\begin{array}{l}\text { Friends, } \\
\text { relatives } \\
\text { informed } \\
\text { me } \\
15\end{array}$} & \multirow{2}{*}{$\begin{array}{c}\text { Other } \\
\text { sources } \\
8\end{array}$} & \\
\hline & Aged $18-49$ & $\mathrm{~N}$ & & & & & & \\
\hline & & $\begin{array}{l}\text { per cent } \\
\%\end{array}$ & $28.0 \%$ & $13.6 \%$ & $40.0 \%$ & $12.0 \%$ & $6.4 \%$ & $100.0 \%$ \\
\hline & Aged $50-64$ & $\mathrm{~N}$ & 10 & 3 & 7 & 8 & 0 & 28 \\
\hline & & $\begin{array}{l}\text { per cent } \\
\%\end{array}$ & $35.7 \%$ & $10.7 \%$ & $25.0 \%$ & $28.6 \%$ & $0.0 \%$ & $100.0 \%$ \\
\hline & Aged 65 and & $\mathrm{N}$ & 10 & 5 & 4 & 0 & 1 & 20 \\
\hline & over & $\begin{array}{l}\text { per cent } \\
\%\end{array}$ & $50.0 \%$ & $25.0 \%$ & $20.0 \%$ & $0.0 \%$ & $5.0 \%$ & $100.0 \%$ \\
\hline \multirow[t]{2}{*}{ In total } & & $\mathrm{N}$ & 55 & 25 & 61 & 23 & 9 & 173 \\
\hline & & $\begin{array}{l}\text { per cent } \\
\%\end{array}$ & $31.8 \%$ & $14.5 \%$ & $35.3 \%$ & $13.3 \%$ & $5.2 \%$ & $100.0 \%$ \\
\hline
\end{tabular}


Table 9. Distribution of the respondents' waiting time to see a physician by age group (per cent) $\left(\chi^{2}=18.592, d f=8, p=0.17\right)$

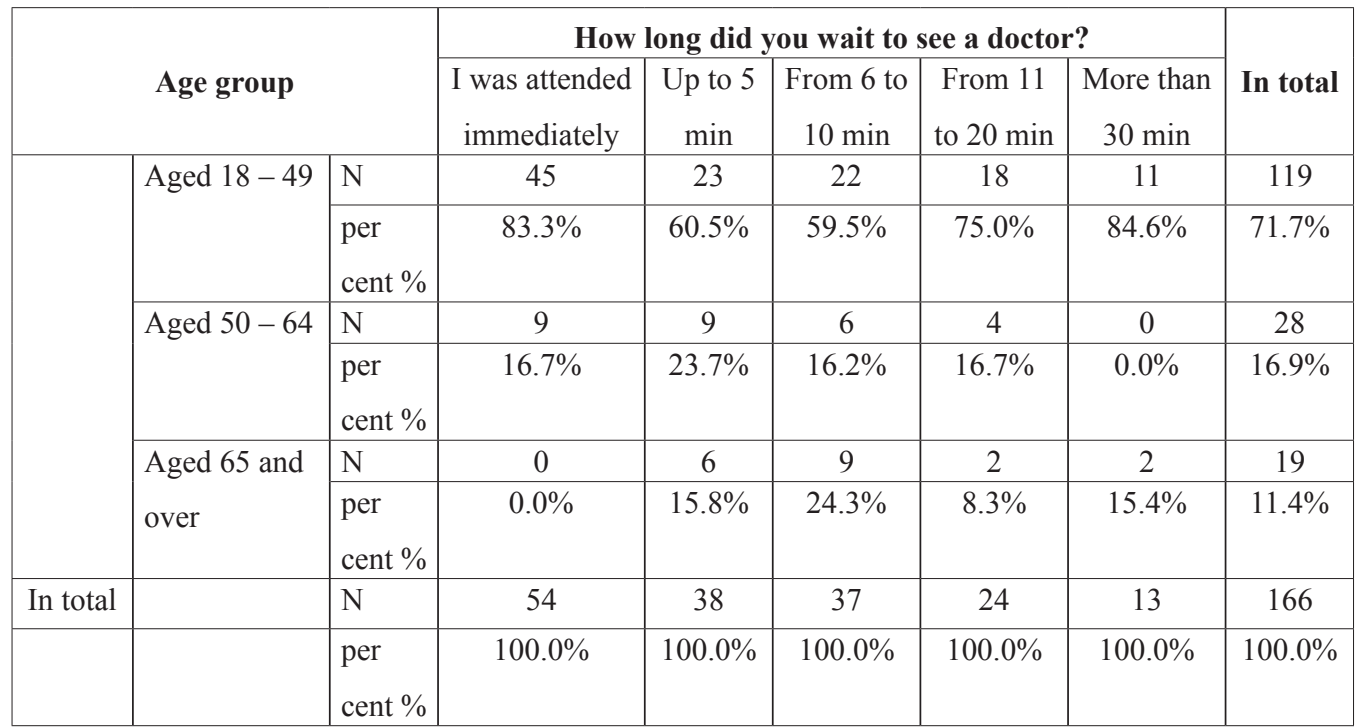

patients included in the age group from 18 to 49 years old (83.3 per cent) pointed out that they did not have to wait at all, i.e. they were attended immediately, compared with older patients (Table 9).

2.5. Out-of-hours service availability and performance analysis by respondents' education

The respondents' education status did not have any impact on the respondents' opinion on the organisation of out-of-hours service and the quality of the services provided. The respondents, regardless of their education status, provided a positive evaluation of the waiting time to see a doctor $\left(\chi^{2}=16.939, \mathrm{df}=12, \mathrm{p}=0.152\right)$, the quality of health care services provided by doctors at out-of-hours service $\left(\chi^{2}=1.373, \mathrm{df}=3, \mathrm{p}=0.712\right)$ and nurses $\left(\chi^{2}=4.446\right.$, $\mathrm{df}=3, \mathrm{p}=0,217)$, doctors' qualification $\left(\chi^{2}=8.186, \mathrm{df}=9\right.$, $\mathrm{p}=0.515)$, organisation of work at out-of-hours service $\left(\chi^{2}\right.$ $=8.263, \mathrm{df}=6, \mathrm{p}=0.219$ ).

2.6. The analysis of the availability and performance of out-of-hours service by respondents' registration with PHCI

The analysis of the respondents' views on the qualification of physicians providing care at out-of-hours service by the respondents' registration with PHCI, did not show any statistically significant difference between the respondents' registration with $\mathrm{PHCI}$ and doctors' qualification $\left(\chi^{2}\right.$ $=1.957, \mathrm{df}=3, \mathrm{p}=0.581$ ), although doctors' qualification was much better assessed by patients of PI "Centro poliklinika" (69.8 per cent).

The analysis of the patients' opinion regarding the changes observed in the quality of work organisation and

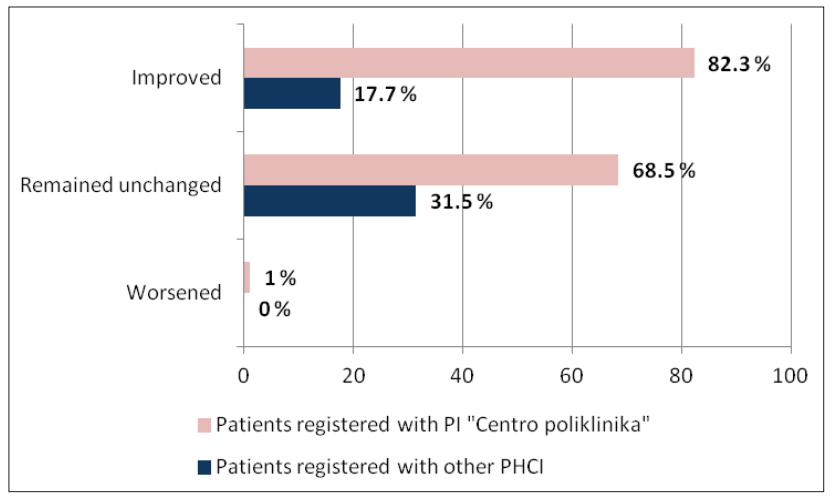

Figure 5. Distribution of evaluation of quality of work organisation and care provision at out-of-hours service by respondents' PHCI (per cent)

$\left(\chi^{2}=3.718, d f=2, p=0.156\right)$

care provision at out-of-hours service over the past two years, no statistically significant difference between the patients and the registration with PHCI was found $\left(\chi^{2}=\right.$ $3.718, \mathrm{df}=2, \mathrm{p}=0.156)$. Therefore, we can state that the patients' registration with their selected PHCI did not impact the evaluation of the quality of work organisation and care provision at out-of-hours service (Figure 5).

\section{Conclusions}

1. In summary, these findings suggest that care provision by out-of-hours service is appropriate in aiming to improve and ensure access to health care within the scope of a family doctor's medical norm. Patients, regardless of 
gender, age and education, gave a positive evaluation of the quality of care provided by out-of-hours service.

2. Health care services delivered after office hours of PPHCI is a new area of the primary health care system, therefore, it is necessary to monitor, investigate and record the non-compliance and quality of the provision of these services.

3. The patients are satisfied with care delivered by out-of-hours service at PI "Centro poliklinika", healthcare provision was ranked as excellent by the vast majority of patients. The study revealed that women showed a stronger demand of out-of-hours service care provision, also older patients lack consultations provided by medical specialists.

\section{Suggestions}

On the basis of the data and findings obtained from this study, the authors provide the following suggestions at the health care provision level:

- Expansion of out-of-hours service operation in major cities by defining specific operational aspects and strategic development.

- Preparation of legal acts regulating the operation of out-of-hours service.

- Financing of out-of-hours service medical care provision by the Compulsory Health Care Insurance Funds.

- Implementation of e-health solutions and opportunities in patient care provision care at out-of-hours service.

\section{References}

1. Care Quality Commission. Our new approach to the inspection of NHS GP out-of-hours services: findings from the first comprehensive inspections. October 2014; 8.

2. Care Quality Commission. Our new approach to the inspection of NHS GP out-of-hours services: findings from the first comprehensive inspections. October 2014; 11.

3. Clay H. Benchmark of out of hours. An overview across the services. Report from the Primary Care Foundation 19. April 2012.

4. Final report for the National Institute for Health Research Service Delivery and Organisation programme. The impact of changing workforce patterns in emergency and urgent outof-hours care on patient experience, staff practice and health system performance. March 2010.

5. Huibers LA, Moth G, Bondevik GT. et al. Diagnostic scope in out-of-hours primary care services in eight European countries: an observational study. BMC Family Practice 2011; 12(30). http://dx.doi.org/10.1186/1471-2296-12-30

6. Huibers L, Giesen P, Wensing M, Grol R. Out-of-hours care in western countries: assessment of different organizational models. BMC Health Services Research 2009; 9(105). http://dx.doi.org/10.1186/1472-6963-9-105

7. Hunskår S, Hansen EH. Differences in requests to out-of-hours services in Norway 2007; 127:1344-6.

8. Hunskår S, Hansen EH. Working style among regular general practitioners and other doctors in out-of-hours emergency services in Norway 2010; 130:135-8.

9. O'Brien HM, Colin-Thome D, Larner G. Health Committee: Evidence. 11 March 2010; 5.

10. U.S. versus European healthcare costs: the data. 2012; 7(18).

11. VšI Centro poliklinikos direktoriaus $2011 \mathrm{~m}$. lapkričio $10 \mathrm{~d}$. ísakymas Nr. V-130 Dèl minimalių asmens sveikatos priežiūros paslaugų kokybės reikalavimų aprašo patvirtinimo".

12. Všt Centro poliklinikos direktoriaus Vadovo ataskaita", 2013; 93.

\section{VŠI CENTRO POLIKLINIKOS BUDINČIO GYDYTOJO TARNYBOS PASLAUGU VEIKLOS ASPEKTAI K. Štaras, A. Juodaitè-Račkauskienė, D. Čepuraitė}

Raktažodžiai: pirminè asmens sveikatos priežiūra, asmens sveikatos priežiūros įstaiga, Budinčio gydytojo tarnyba, būtinoji pagalba.

\section{Santrauka}

Straipsnyje apžvelgiama VšI Centro poliklinikos Budinčio gydytojo tarnybos veikla ketverių metų laikotarpiu, teikiamų paslaugų spektras, darbo specifika ir rezultatai. Analizuojamos ir lyginamos užsienio šalių patirtys minètoje srityje. Pateikiami $2014 \mathrm{~m}$. spalio gruodžio mèn. atlikto tyrimo, taikant anketinès apklausos metodą, kuriame dalyvavo 173 respondentai, kreipęsi į Budinčio gydytojo tarnybą, rezultatai. Analizuojama ambulatorinejje asmens sveikatos priežiūros įstaigoje Budinčio gydytojo tarnyboje dirbančių gydytojų ir slaugytojų teikiamų asmens sveikatos priežiūros paslaugų kokybė ir šių paslaugų poreikis pacientams. Tyrimo metu nustatytas asmens sveikatos priežiūros paslaugų prieinamumas kitų ambulatorinių asmens sveikatos priežiūros įstaigų nedarbo metu, nustatyti laiko sąnaudų ryšiai su respondentų charakteristikomis bei numatytos galimos Vš I Centro poliklinikos Budinčio gydytojo tarnybos veiklos bei struktūros tobulinimo perspektyvos.

Adresas susirašinèti: kestutis.staras@pylimas.lt

Gauta 2015-08-14 